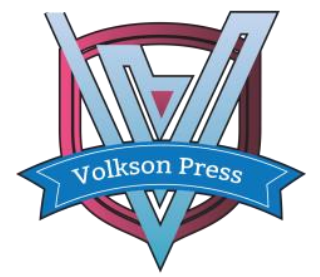

Contents List available at VOLKSON PRESS

Economics \& Management Innovations(EMI)

DOI : http://doi.org/10.26480/icemi.01.2017.339.342

\title{
Implementation of the Model of Maturity to Agility Assessment
}

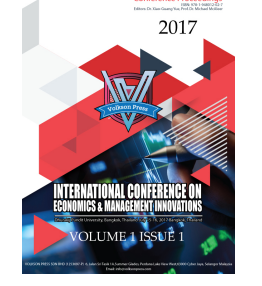

Agnieszka Stachowiak $^{1, *}$, Anna Mazur ${ }^{2}$

${ }^{1}$ Faculty of Engineering Management, Poznan University of Technology, 11 Strzelecka Str, 60-965 Poznan, Poland

${ }^{2}$ Faculty of Engineering Management, Poznan University of Technology, 11 Strzelecka Str, 60-965 Poznan, Poland

*agnieszka.stachowiak@put.poznan.pl

This is an open access article distributed under the Creative Commons Attribution License, which permits unrestricted use, distribution, and reproduction in any medium, provided the original work is properly cited.

\section{ARTICLE DETAILS}

\section{Article History:}

Received 02 october 2017 Accepted 06 october 2017 Available online 11 october 2017

\section{Keywords:}

agility, maturity, maturity assessment, fuzzy index of organizational

\section{ABSTRACT}

The goal of this paper is to present the authors' model of organizational maturity assessment taking into account the context of agility of enterprises together with the framework of method of assessment of organizational maturity. The developed model is utilitarian, the authors implement triangular fuzzy numbers and the fuzzy index of organizational maturity as the way of assessing organizational maturity. This paper also presents the way to implement and benefit from the assessment of the level of organizational maturity in the context of agile management on the example of the company operating within the furniture industry in Poland.

\section{Introduction}

The imminent characteristics of the market in Poland and in the world is the increasing demands of stakeholders and competition, which both are driving companies to think in the long run. This is directly related to the concept of improvement, which in business practice is often associated with the principle of continuous improvement, the basic idea of many proquality standards. The pursuit of better and better results motivates the company to implement various types of solutions aimed at improving organizational processes, minimizing the risk of errors and incompatibilities, as well as ensuring the reproducibility of the quality of the manufactured products or services. One such solution is the concept of business agility, which is implemented by organizations wishing to cope with the volatility of market in which they operate.

The goal of this paper is to present the original authors' model of organizational maturity assessment taking into account the context of agility of enterprises together with the framework of method of assessment of organizational maturity. The developed model is utilitarian, the authors implement triangular fuzzy numbers and the fuzzy index of organizational maturity as the way of assessing organizational maturity. This paper also presents the way to implement and benefit from the assessment of the level of organizational maturity in the context of agile management on the example of the company operating within the furniture industry in Poland.

\section{Organizational maturity and its assessment according to IS09004:2010}

Mature organizations are those that: stand out among others, enjoy a good reputation among their clients, manage their finances efficiently, strive for continuous development while seeking innovative, technical, organizational and managerial solutions. Organizational maturity is also characterized by [1]:

- ability to plan in the long term while monitoring and responding to changes in the environment,

- $\quad$ ability to identify interested parties, identify stakeholder needs and inform them about the organization's plans and actions,

- $\quad$ ability to use modern valuation methods and a sustainable way of meeting stakeholder needs,
- $\quad$ correctness in building lasting and favorable relationships with suppliers, suppliers and partners,

- $\quad$ ability to identify, assess and minimize risks associated with strategic decision-making,

- $\quad$ ability to regularly assess compliance with adopted plans and procedures to effectively implement corrective and preventive actions,

- focusing on continuous development of the organization through continuous improvement of employees' competences, continuous learning and improvement of know-how.

With regard to organizations, maturity is to be understood as achieving full development with the possibility of achieving excellence. However, it must be borne in mind that achieving a certain level of maturity is not equivalent to achieving excellence, because excellence requires continuous improvement [2]. Analysis and evaluation of organizational maturity is essential in pursuit of excellence. Organizational maturity is the result of maturity of business processes resulting from the organization's activities and the maturity of the teams performing these processes [3]. In the subject literature several models of organizational maturity assessment can be found. One of them is the model presented in the ISO 9004 standard. In the ISO 9004: 2001 standard "Quality management systems guidelines for improvement of functioning" five levels of organizational maturity are defined: lack of formal approach, passive approach, formal and stable system approach, emphasis on continuous Improvement and the highest level, the best in the field. The characteristics of organizational maturity levels are presented in Figure 1. 


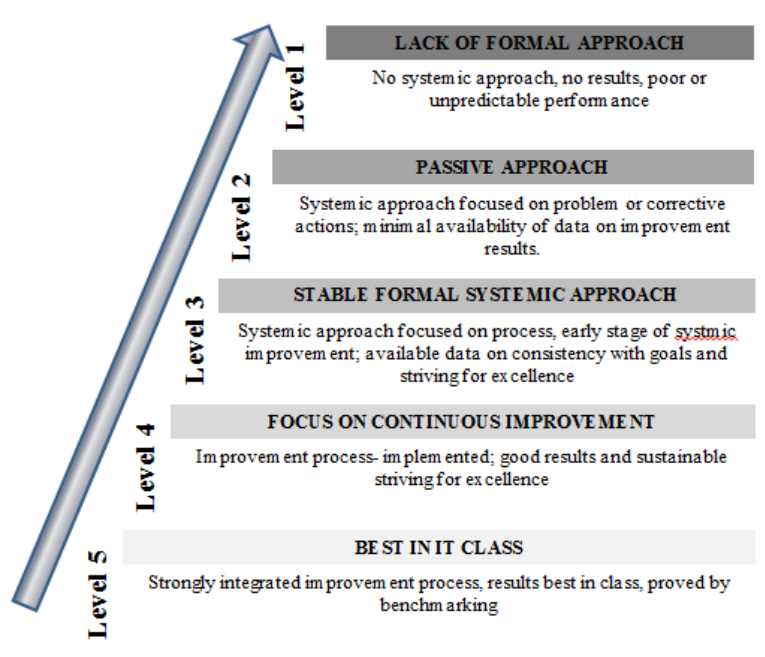

Figure 1. Organizational maturity levels according to ISO 9004 [own work based on: 4]

In the next update of the standard, i.e. in ISO 9004: 2009, "Management towards a sustainable organization success, a quality management approach" a model for self-assessment of organizational maturity with respect to the key elements of the organization's functioning and to the detailed elements grouped in the following areas is presented. It refers to [1]:

\section{- focusing on sustainable organization success, \\ - $\quad$ strategy and policy, \\ - resources management,}

- process management,

- monitoring, measurement, analysis and review,

- improvement, innovation and learning.

The self-assessment method presented in the standard allows the organization to obtain information and knowledge about its current maturity, which is a prelude to making further improvement decisions.

\section{Agile management idea}

Agility is a desirable feature in modern companies, which have to cope with difficult market conditions resulting from dynamics, volatility of market conditions which is also called turbulent environment, hypercompetition, technical and technological progress. It should be noted that turbulence of the environment and sustainability are now considered to be two of the most significant paradigms in management sciences $[5,6]$. The response to these metaparadigms is the concept of agility understood as the ability to cope with volatility, a concept that has been present in management for over twenty years. According to Trzcielinski, agility is the ability to use emerging opportunities thanks to such features as cleverness, flexibility, intelligence and smartness [7]. Hence, agility is a comprehensive response to the business challenges of achieving profitability in dynamically changing global markets characterized by high quality, performance and personalization of the goods and services offered [8]. Agility is achievable if it is understood as a set of interrelated changes in marketing, production, design and organization [9]. The essence of agile management is firmly based on customer engagement, as it is also understood as the ability of an enterprise to survive through rapid and effective response to market changes driven by customer-designed products and services. Achieving agility is not easy, requires commitment, activity, and therefore a key driving force for agility is its need, intent, and agile strategy. But not every organization, even seeing the need to increase its agility, is able to design and implement agile strategy. According to the authors, this is the result of the lack of willingness to implement agile management, especially since it is a dedicated strategy, dependent on individual internal and external conditions. The cause of this situation is often lack of awareness of the current level of agility of the organization, moreover, lack of knowledge about areas requiring improvement in the context of agility [17]

\section{Model of Maturity to Agility Assessment (MMAA)}

One of the most important models of agility is Sharif and Zhang's agility model, which covers three key aspects: agility drivers, agility competences, and agility features $[8,12]$. The model logic assumes gaining agility competency through specific practices, methods, and tools within the agility strategy implemented. The authors propose that the list of driving forces of agility was supplemented by maturity to agility levelled in the following form:

- need to achieve agility,

- strategic intention to achieve agility,

- maturity to achieve agility,

- agile strategy.

The maturity to agility can be determined by the current level of agility and the level of agility competences, and by identifying the gaps in this context, the gaps that will allow proper formulation of a dedicated agility strategy appropriate for a given level of maturity.

Taking into account the familiar organizational maturity models for the agile management context, you can define the following maturity levels presented in Figure 2:

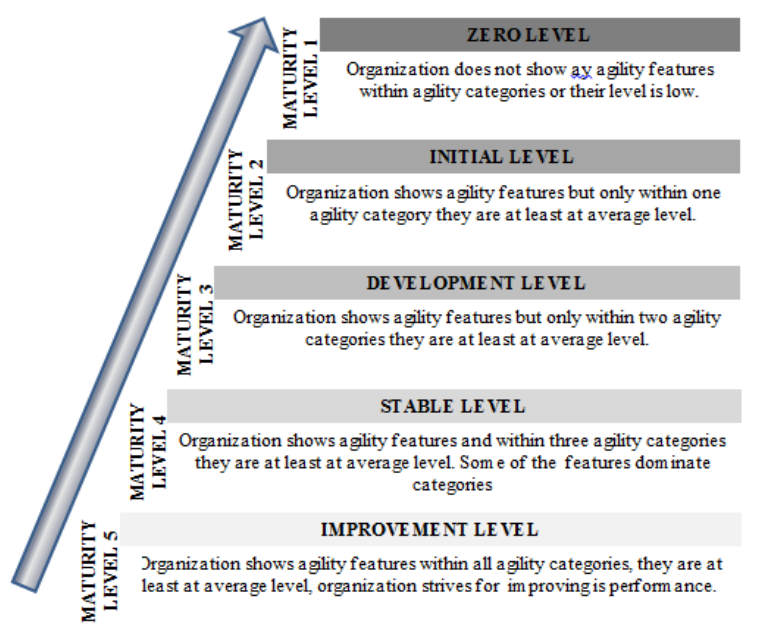

Fig 2. Maturity to agility levels (own work based on [7, 8,12])

Agility categories (Smart, Intelligent, Flexible, Clever, as defined in the definition by Trzcielinski presented in the previous section) may have different levels of complexity, but their complexity and character do not allow numerical expression of these levels. Qualitative leveling is based on the intuitive application of linguistic variables, according to the proposed scale:

- $\quad$ highest possible level (HPL)

- $\quad$ high level (HL)

- $\quad$ average level (AL)

- $\quad$ low level (LL)

- $\quad$ no feature (NF).

Companies rated in terms of agility competence determine their level, which determines maturity levels, and design an appropriate agility strategy based on dedicated practices, methods, and tools. The authors developed the model of organizational maturity assessment in the context of agile management (MMAA).

The model is based on a continuous improvement cycle and involves assessing the agility of the company in the context of its: smartness, intelligence, flexibility and cleverness (SIFC) in the a way enabling, from the analysis and assessment of agility, by identifying the level of maturity in this context, definition of improvement activities which will be included in the agile strategy of the organization. This strategy, through agility drivers (appropriately selected and implemented methods and tools) will help organizations move towards agility and effectively operate in a turbulent environment, while striving to meet stakeholder requirements, standards requirements, specifications, and other regulations to which an 
enterprise is subject. To evaluate organizational maturity in the context of agile management, the author proposes the use of triangular fuzzy numbers and the use of fuzzy index of organizational maturity. Application of elements of fuzzy sets theory [13] in management, inter alia to assess the agility of the supply chains [10] or to measure the agility of the manufacturing units [11] is justified by the difficulty of quantifying the scores, so the authors adapted fuzzy agility measures to assess maturity by defining the Fuzzy Index of Organizational Maturity (FIOM). This indicator is based on linguistic variables and linguistic values, converted to triangular numbers fuzzy in the fuzzification process. The fuzzy numbers obtained by the evaluation procedure are aggregated into weighted fuzzy average by the elimination of max pairs. The result obtained in the form of a fuzzy number is converted back into a linguistic value in the defuzzification process so that the result of the evaluation is easy to analyze. When converting, the Euclidean distance method is used. The average fuzzy of individual ratings (ie RWDO) is derived from the following formula:

$$
\operatorname{FIOM}_{j}=\frac{\sum_{i=1}^{n} R_{i}}{n}
$$

where:

FIOMj - Fuzzy Index of Organizational Maturity in the $\mathrm{j}$ category

j- category number

$\mathrm{R}_{\mathrm{i}}$ - level of i feature,

i - number of the feature,

$\mathrm{n}$ - number of features applied for assessment.

The level of each category is defined in the study so as to define the level of organizational maturity.

The fitness function can be defined as follows:

$$
f_{\text {FIOM }}(y)=\sup \cdot \min .\left\{f_{R i}\left(R_{i}\right), i=1 . . n, y=\frac{\sum_{\mathrm{i}=1}^{\mathrm{n}} \mathrm{R}_{\mathrm{i}}}{\mathrm{n}}\right\}
$$

where:

for each $i=1,2, \ldots, n, f_{R i}$ is fitness function referred to $R_{i}$.

The max-min pair elimination procedure for calculating the function is shown in [7]

The Fuzzy Index of Organizational Maturity is a fuzzy number, so the next step must be to restore meaning to it, by replacing it with a linguistic term, or natural language. There are several methods of converting fuzzy numbers into values and linguistic terms generally speaking they can be divided into the following three techniques:

\section{determining the Euclidean distance;}

progressive approach;

decomposition.

With regard to the presented FIOM, a method based on the calculation of the Euclidean distance between a given fuzzy number and each fuzzy number representing the range of natural language expressions is used $[10,13]$.

\section{Implementation of MMAA}

All the companies need to develop and improve, and production and manufacturing industry has a great potential for innovation, and as result agility $[14,15]$. However, to assess progress, methods and tools must be implemented to identify present condition. The MMAA not only assess an organization, but also enables definition of strategy for development.

The essence of the MMAA implementation is illustrated by the example presented in the case study. The case study is executive research, as it is an example of the application of triangular fuzzy numbers in the assessment of organizational maturity in the context of agile management. The company selected for the analysis is a medium-sized furniture company, a producer of system and office furniture. The furniture industry is one of the smart industries identified for Wielkopolska region. It is also one of the industries with potential for agility as it assumes a certain range of assortment variability in response to customer orders, adapting to changing technologies, new materials, assumptions and constraints resulting from environmental policies. The company therefore demonstrates the need for agility as a prerequisite for agile management. Implementing the assumptions of the model also assumes a strategic intention of agility, which is manifested by the involvement of the enterprise and the establishment of agility team. The team, in addition to the authors (who are consultants in the discussed field) included representatives of the most important functional areas of the company (design, manufacturing, marketing, finance, quality) and a top management representative. The goal of the team was to identify the current level of agility and to formulate, in line with the assumptions of the model, the recommendations for improvement. The assessment was preceded by workshop organized by consultants which purpose was to clarify the idea of agility, the scope of the conceptual categories of agility and the method of assessment, along with the terms used to assess the features. According to the adopted methodology, all the identified features were assessed under the scale of: HPL: highest possible level, HL: high level, AL: average level, LL: low level, NF: (no feature) lack of any manifestations of competence. The agility team was presented a sheet, and its components were characterized. At the next meeting, the members of the team made a judgment based on their own knowledge and experience. The individual results were aggregated according to the methodology presented in the previous chapter, which allowed to determine the index of organizational maturity. Interpretation of the obtained results allowed to assess the maturity level in the context of agility, as well as to define gaps and areas requiring improvement, and consequently to develop a dedicated agility strategy for the enterprise. The MMAA implementation procedure is illustrated with Figure 3.

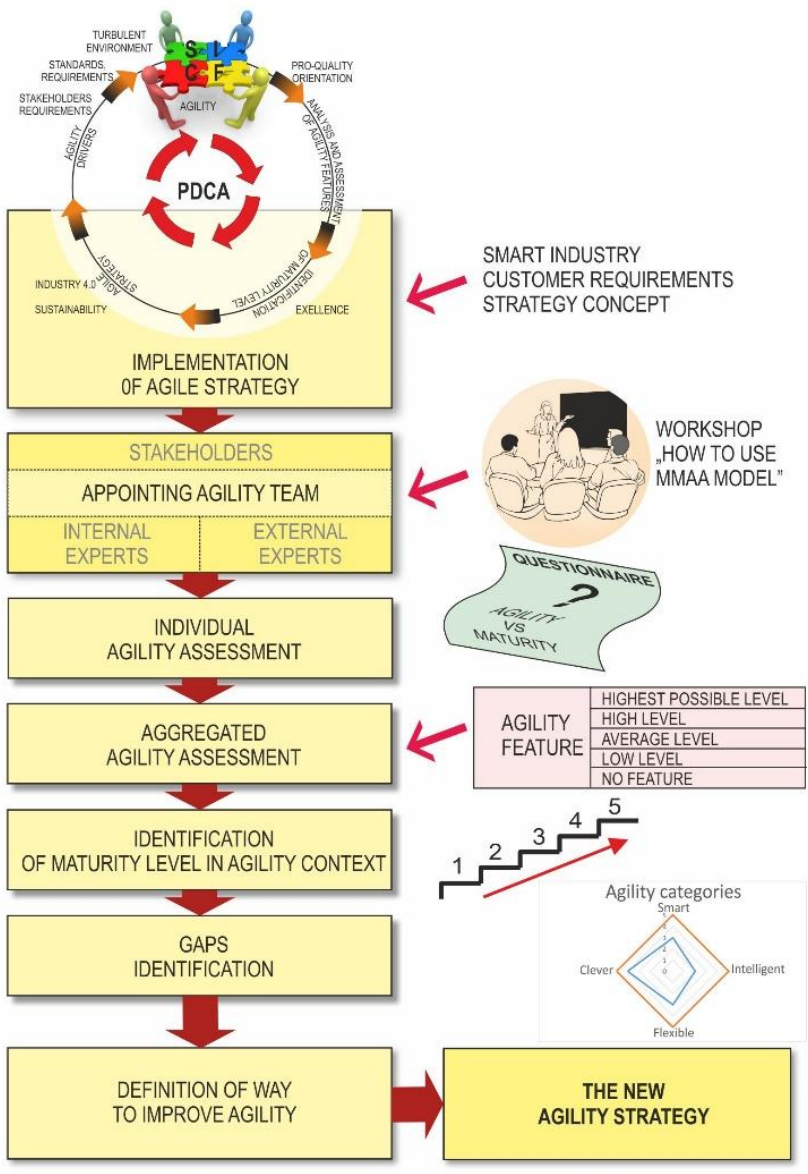

Fig 3. Implementation of MMAA

Source: Own work

The results obtained in the form of linguistic evaluations in accordance with the adopted methodology were fuzzified to determine the ratings for each category and determine the level of maturity. The resulting partial results are shown in Table 6, in the form of fuzzy numbers and the result obtained in the form of a linguistic expression after defuzzification, allowing the interpretation of the assessment.

Table 1. Maturity level assessment

\begin{tabular}{|l|l|l|}
\hline Category & Assessment result & Interpretation \\
\hline Smart & $(4,13 ; 5,73 ; 7,33)$ & AL: average level \\
\hline Intelligent & $(2,67 ; 4,27 ; 7,87)$ & LL: low level \\
\hline Flexible & $(4,2 ; 5,8 ; 7,07)$ & AL: average level \\
\hline Clever & $(4,7 ; 6,2 ; 7,15)$ & HL: high level \\
\hline
\end{tabular}


The result showed a high, because the fourth level of maturity, referred to as stable (see Figure 2), since the level of three of the four agility categories was rated as average or higher. Dominant categories of agility are: cleverness, flexibility, smartness. The complete composition is lacking in intelligence, so the company does not fully utilize the competences of its employees, or does not have all the competences it requires (Figure 4).

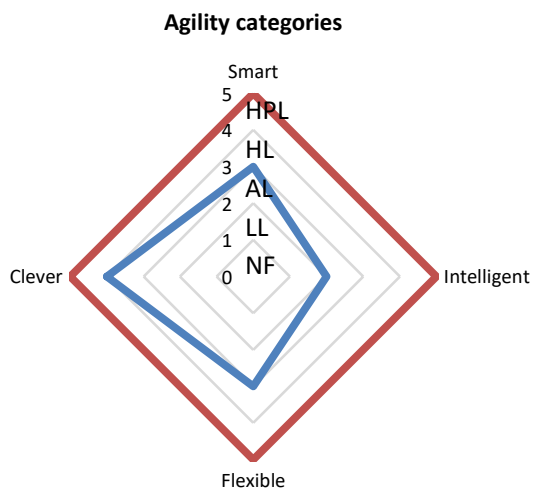

Fig. 4. Maturity in the context of agility assessment

Source: own study

A strategy for agility should be focused on gaining intelligence features, such as the ability to learn, collect and transform knowledge, and then improve the characteristics of each category.

\section{Summary}

Agility, as one of the paradigms of modern day management requires a company to be constantly ready to change, react, and even overtake the impulses emerging in the environment, it needs to change and grow, it needs to mature $[18,19,20,21]$. It is not an easy task, and moreover, it is not a task that can be fulfilled and considered complete. As the environment changes, the organization must change and thus improve, but managers need to be aware of where the change is heading, what the business lacks in order to achieve agility $[22,23]$. The answer to this problem is the concept of organizational maturity assessment in the context of agile management presented by the authors, as it allows to define the level within particular agility categories, and on this basis defines gaps and areas requiring improvement actions. The research area presented here still shows great potential. In subsequent studies, the authors plan to expand or redefine the list of agility features, and to take into account the importance of individual features and criteria.

\section{References}

[1] ISO 9004:2009 Managing for the sustained of an organization - A quality management approach, 2009

[2] E. Skrzypek „Uwarunkowania i konsekwencje osiągania dojrzałości organizacyjnej $\mathrm{w}$ warunkach zmienności otoczenia" in: Dojrzałość organizacji - Aspekty jakościowe. Skrzypek E. (red.). s. 35-46. Lublin: Uniwersytet Marii Skłodowskiej Curie w Lublinie, 2013

[3] A. Skrzypek „Dojrzałość organizacyjna i jej wpływ na doskonalenie zarządzania przedsiębiorstwem" Problemy Jakości 2014 nr 11/2014, s. 812.

[4] ISO 9004:2001, Quality management systems - Guidelines for performance improvements

[5] W.M. Grudzewski, I. K. Hejduk, „Przedsiębiorstwo przyszłości. Zmiany paradygmatów zarządzania" Master of Business Administration 1/2011 (116). s. 95-111. Warszawa: Akademia Leona Koźmińskiego
[6] A. Pietruszka-Ortyl, „Szkice o paradygmatach wyłaniających się w naukach o zarządzaniu" in: Historia i perspektywy nauk o zarządzaniu. Mikuła B. (red.) Kraków: Fundacja Uniwersytetu Ekonomicznego 2010 [7] S. Trzcieliński. 2011. Przedsiębiorstwo zwinne. Poznań: Wydawnictwo Politechniki Poznańskiej.

[8] H. Sharifi, D. Zhang 1999. A methodology for achieving agility in manufacturing organisations: An introduction. International Journal of Production Economics 62.1. p. 7-22.

[ 9] J. Storey, C. Emberson, D. Reade "The barriers to customer responsive supply chain management" International Journal Operations \& Production Management, 2005, 25(no 3), p. 242-260.

[10] L. Ching-Torng „Agility Index in Supply Chain“, Proceedings of the 17th International Conference on Production Research August 3-7. Blacksburg, Virginia USA, 2003

[11] A. Stachowiak „Zwinne przedsiębiorstwo - wyznaczniki i ocena zwinności" in: Nowoczesne przedsiębiorstwo, Trzcieliński S. [red.]. Poznań: Wyd. Politechnika Poznańska, 2005.

[12] A. Gunasekaran "Agile manufacturing: a framework for research and development",. International Journal of Production Economics, 1999, 62.1. p. $87-105$

[13] A. Piegat „Modelowanie i sterowanie rozmyte” Warszawa: Akademicka Oficyna Wydawnicza EXIT 1999

[14] I. Gabryelewicz, J. Sadłowska-Wrzesińska, E. Kowal "Evaluation of safety climate level in a production facility" Procedia Manufacturing: 6th International Conference on Applied Human Factors and Ergonomics (AHFE 2015) and the Affiliated Conferences, AHFE 2015, Elsevier. B.V., pp. 6211-6218

[15] K. Firlej, A. Kowalska, A. Piwowar „Competitiveness and innovation of the Polish food industry“ in: Agricultural Economics - Czech, 63, 2017, No.7: 298

[16] S.L Goldman., R.N. Nagel, K. Preiss "Agile Competitors and Virtual Organizations: Strategies for Enriching the Customer", New York, NY: Van Nostrand Reinhold 1995

[17] K. Grzybowska, A. Łupicka „Knowledge Acquisition in Complex Systems", Proceedings of the 2016 International Conference on Economics and Management Innovations, part of Advances in Computer Science Research vol 57, ISSN 2352-538X, Yue X.-G., Duarte N.J.R. (eds.), pp. 262 266, DOI: 10.2991/icemi-16.2016.5

[18] Řepa V., Šatanová A., Lis M., Korenková V., 2016, Organizational development through process based management: a case study, International Journal For Quality Research, vol. 10, no. 4, pp.685-705.

[19] Yazdanpanah A. A., Ehsani A., Tilami S. K., Karami H., 2015, Defining of Evaluating Models of Organizational Maturity for Applying Effective and Efficient Model of Management Information Systems, International Journal of Scientific Management \& Development, Vol. 3 no. 8, pp. 497-502.

[20] Kasse T., Johansen J., 2014, Maturity differences between customer and supplier-challenges, problems, and possible solutions, Journal of Software: Evolution \& Process; Vol. 26, no. 3, pp 295-305.

[21] Kamalanabhan T., Kothandaraman K., 2017, A Scale to Measure Perceptions of Organizational Maturity, Psychological Studies, vol. 62, no. 1, pp. 47-59.

[22] Linkevics G., Sukovskis U., 2015, Evaluation of the Agility Level of the Organization, Applied Computer Systems, vol. 18, no. 1, pp. 21-26.

[23] Mendes, Jr.P., Leal J.E., Thome, A. M.T., 2016, A maturity model for demand-driven supply chains in the consumer product goods industry, International Journal of Production Economics, Vol. 179, pp. 153-165. 